\title{
O automatismo psicológico. Ensaio de psicologia experimental sobre as formas inferiores da atividade humana*
}

Pierre Janet

\section{Conclusão}

(...), passemos, agora, à psicologia pura e busquemos em suas leis a explicação da atividade particular e automática que queremos estudar. As coisas parecem ocorrer como se existissem na mente duas atividades diferentes que ora se completam, ora se estorvam: consideremos cada uma separadamente.

Como diziam os filósofos antigos, ser é agir e criar; logo, por ser uma realidade no mais alto grau, a consciência não pode senão ser uma atividade que age. Se buscarmos nos representarmos sua natureza, essa atividade é essencialmente uma atividade de síntese que reúne um maior ou menor número de dados fenômenos num fenômeno novo, diferente dos seus elementos. Esta é uma verdadeira criação, pois, independentemente do ponto de vista que adotarmos, "a multiplicidade não contém a razão da unida-

* Publicado em Paris em 1889. Tradução: Alain François. Revisão técnica: Prof. Dr. Mário Eduardo Costa Pereira, Laboratório de Psicopatologia Fundamental-Unicamp. 
de", ${ }^{1}$ e o ato pelo qual elementos heterogêneos são reunidos numa nova forma não está dado nesses elementos. No momento em que, pela primeira vez, um ser rudimentar reuniu fenômenos para deles fazer uma sensação vaga de dor, houve uma verdadeira criação no mundo. Essa criação se repete em cada novo ser que consegue formar uma consciência desse gênero, pois, na verdade, a consciência desse ser que acaba de nascer não existia no mundo e parece surgir do nada. Portanto, por si mesma, e desde seus primórdios, a consciência é mesmo uma atividade de síntese.

É impossível dizer quais elementos foram assim combinados primeiros pela consciência. Do mesmo modo que a fisiologia encontra organização em todos os elementos do corpo organizado, a psicologia já encontra uma organização e uma síntese em todos os elementos da consciência aos quais consegue remontar. Entretanto, o que está certo é que existem graus de organização e de síntese cada vez mais complexos. As pequenas sínteses elementares insistentemente repetidas tornam-se elementos de outras sínteses superiores. Por serem mais complexas, essas novas sínteses são bem mais variadas que as anteriores, e, embora continuem sendo unidades, são unidades cujas qualidades diferem entre si. Do mesmo modo que os seres compostos de uma única célula são todos semelhantes, e que os seres compostos de várias células começam a tomar formas distintas, as consciências vagas de prazer e de dor se tornam paulatinamente sensações determinadas, mas de tipos diferentes. Cada sensação é assim um todo, um composto no qual foram combinados elementos de consciência, os quais correspondem, por sua vez, a movimentos muito simples. Não se pode dizer que uma criança aprende a sentir tal sensação e que, em seguida, aprende a fazer o movimento complexo correspondente: aprende as duas coisas simultaneamente e a coordenação dos movimentos se dá ao mesmo tempo que a organização dos elementos da sensação.

Por sua vez, essas sensações organizam-se em estados mais complexos, que podemos chamar de emoções gerais; estas se unificam e formam, a cada momento, uma unidade particular que denominamos de idéia da personalidade, ao passo que outras combinações vão formar as diferentes percepções do mundo exterior.

Algumas mentes vão mais longe e sintetizam essas percepções em juízos, em idéias gerais, em concepções artísticas, morais ou científicas. Desperta a nossa atenção, então, a atividade criadora da mente; não acreditamos que as altas sínteses científicas feitas por certos homens de gênio lhes tenham sido dadas nos

1. Boutroux. De la contingence des lois de la nature, 1874, p. 9. 
elementos fornecidos pelas sensações. Por bem sabermos que gerações de homens possuíram esses mesmos fatos, esses mesmos elementos, e não conseguiram coordená-los, dizemos que o gênio é criador. Contudo, a natureza da consciência é sempre a mesma e a criança que, pela primeira vez, construir em si a mais fraca das emoções artísticas ou religiosas também realiza, por sua própria conta, uma descoberta e uma criação. "A percepção não difere da associação", dizia Fouillée; "é sempre a introdução de uma corrente superior de força irresistível à qual todo o resto se subordina e que arrasta tudo em seu círculo próprio..."2 Como, por quais progressos lentos, a consciência efetua tais sínteses e em que ordem passa de uma à outra? São coisas que não estudamos aqui, pois, por sempre supormos que essa primeira atividade já tinha feito sua obra, sempre estudamos as conseqüências de seu trabalho.

Há na mente humana, entretanto, uma segunda atividade para a qual não consigo achar um nome melhor do que atividade conservadora. Uma vez construídas, as sínteses não se destroem; duram, conservam sua unidade, guardam seus elementos arrumados na ordem em que foram ajeitados. Basta estarmos em circunstâncias favoráveis para vermos as sensações ou as emoções se prolongarem tanto quanto possível com todos seus caracteres. Mais ainda, se a síntese precedentemente realizada não se deu por completo, se na mente existem apenas alguns de seus elementos, essa atividade conservadora vai completá-la, acrescentando os elementos ausentes na ordem e no modo necessários para reconstituir o todo primitivo. Do mesmo modo que a atividade precedente tendia a criar, esta tende a conservar, a repetir. A maior manifestação da primeira era a síntese, o grande caráter desta é a associação de idéias e a memória. "É a contraparte mental da grande lei da mecânica que é a conservação da força. Ora, essa lei reza que todo móvel persevera em seu movimento, enquanto outra força não o desviar, e segue sempre a linha de menor resistência. Na mente da criança, uma primeira experiência associou a queimadura à chama e produziu assim certa direção tanto do pensamento como da ação; temos assim, a favor da direção chama-queimadura, uma força positiva e nenhuma outra em sentido contrário". ${ }^{3}$

São as conseqüências dessa lei geral de conservação e de reprodução que examinamos neste trabalho. Vimos as sensações durarem e manterem os elementos que as constituíam, vimos as emoções se reproduzirem e manterem os movimentos e as expressões da fisionomia da qual eram partes constituintes. Sendo dado um elemento de uma memória particular e de uma personalidade comple-

2. Fouillée. Sensation et pensée. Revue des Deux-Mondes, 15 juillet 1884, p. 47.

3. Fouillée. Op. cit, p. 417. 
xa, toda a memória e toda a personalidade se reproduziam. Conforme se traziam assim os elementos de tal ou tal, síntese anteriormente constituída, fazia-se alternar as consciências e as existências pessoais. Por fim, quando o sujeito tinha aprendido o sentido das falas e compreendido a linguagem, provocavam-se, graças às sínteses realizadas anteriormente, todos os atos, todos os pensamentos, faziamse nascer todos os fenômenos psicológicos dentro de uma ordem regular e fácil de se prever. Obviamente, quem quiser ver apenas um lado da mente pode deter-se naquele automatismo que descrevemos em detalhes. Para nós, entretanto, ele não passa de conseqüência de outra atividade completamente diferente, que, por já ter agido no passado, tornou-o possível hoje e, por sinal, ainda o acompanha quase sempre.

De fato, essas duas atividades costumam coexistir enquanto o ser está vivo; de sua sintonia e de seu equilíbrio dependem a saúde do corpo e a harmonia da mente. Assim como num estado político, a atividade inovadora e a atividade conservadora devem se regular e se limitar mutuamente, na mente, a atividade atual, capaz de compreender novas sínteses e de se adequar a novas condições, deve equilibrar essa força automática que quer manter imutáveis as emoções e as percepções do passado. Quando a mente é normal, ela apenas cede ao automatismo certos atos inferiores que, se as condições permaneceram as mesmas, podem repetir-se sem problemas. Porém, ela está sempre ativa para, a cada instante da vida, realizar as novas combinações que se tornam incessantemente necessárias para manter-se em equilíbrio com as mudanças do meio. Essa união das duas atividades é, portanto, a condição da liberdade e do progresso.

Entretanto, basta a atividade criadora da mente, depois de ter trabalhado no início da vida e acumulado certa quantidade de tendências automáticas, cessar de agir de repente, e descansar antes do fim, para que a mente se torne inteiramente desequilibrada e entregue sem contrapeso à ação de uma única força. Os fenômenos que surgem já não são mais reunidos em novas sínteses, não são mais apreendidos para formar, a cada momento da vida, a consciência pessoal do indivíduo; cabem então naturalmente em seus grupos antigos e acarretam automaticamente as combinações que costumavam ter suas razões de ser. Certamente, se fosse mantida com precaução num meio artificial e invariável, se nela suprimindo a mudança das circunstâncias, evitando-se que se desse ao trabalho de pensar, uma mente dessas poderia subsistir algum tempo, fraca e distraída. Contudo, basta o meio se modificar, ou desgraças, acidentes ou simples mudanças exigirem um novo esforço de adaptação e de síntese, para que ela resvale na mais completa desordem.

Essas desordens todas, pequenas ou grandes, que resultam do predomínio de um automatismo antigo sobre uma atividade sintética atual muito enfraqueci- 
da, são o que estudamos na última parte deste trabalho. Vimos que as mais estranhas perturbações podiam se resumir a algumas leis simples e que a psicologia tinha como explicá-las.

As idéias gerais que acabamos de expor e que, por sinal, podem ser parcialmente encontradas nos trabalhos de vários filósofos contemporâneos, nos pareceram uma maneira simples de resumir, de sintetizar os fenômenos que descrevemos. Elas devem ser consideradas apenas como conjeturas verossímeis. Sua imperfeição ou mesmo sua falsidade não alterariam a exatidão de algumas leis particulares e de determinados fatos que, a nosso ver, são sempre o essencial neste ensaio de psicologia experimental.

Filósofo, psicólogo e psiquiatra francês. Autor, entre outros livros, de L'automatisme psychologique. Essai de psychologie expérimentale sur les formes inférieures de l'activité humaine (1889); Les obsessions et la psychasthénie (1903) e De l'angoisse à l'extase (1926). 